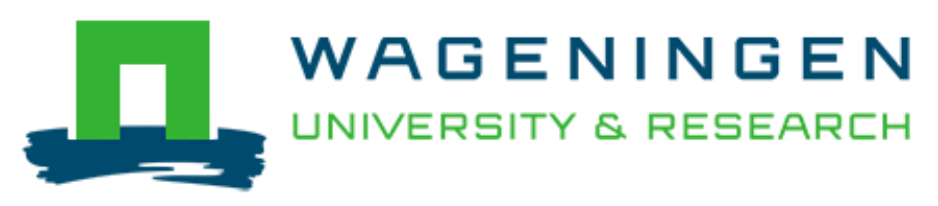

\author{
Depoliticisation in Livestock Farming Governance: Turning Citizen Concerns \\ into Consumer Responsibilities \\ Van Wessel, M.
}

This is a "Post-Print" accepted manuscript, which has been published in "Sociologia Ruralis"

This version is distributed under a non-commercial no derivatives Creative Commons (c) (1) @) ( 9 (CC-BY-NC-ND) user license, which permits use, distribution, and reproduction in any medium, provided the original work is properly cited and not used for commercial purposes. Further, the restriction applies that if you remix, transform, or build upon the material, you may not distribute the modified material.

Please cite this publication as follows:

Van Wessel, M. (2017). Depoliticisation in Livestock Farming Governance: Turning Citizen Concerns into Consumer Responsibilities. Sociologia Ruralis. DOI:

$10.1111 /$ soru. 12194

You can download the published version at:

https://doi.org/10.1111/soru.12194 


\title{
DEPOLITICISATION IN LIVESTOCK FARMING GOVERNANCE: TURNING CITIZEN CONCERNS INTO CONSUMER RESPONSIBILITIES
}

\author{
Margit van Wessel \\ Accepted for publication in Sociologia Ruralis
}

September 2017

\section{Abstract}

The Dutch livestock farming sector faces complex challenges concerning its sustainability and social license to operate. Engaging with what is widely understood as a legitimacy crisis, the Dutch government organised a two-day multi-stakeholder meetings to explore future directions. Participants engaged with the public as a key but absent stakeholder, in ways that contributed to the outcome of the meetings in important ways. The paper charts and analyses how and with what consequences this happened. Findings are that participants discursively constructed citizens in terms of consumer roles, with deliberations turning citizen concerns about livestock farming into questions of consumer responsibility, sidelining citizens' political voices and discursively displacing the possibility of politics around livestock farming. This instance of network governance presents a case of depoliticisation of an issue of concern to citizens, closely related to market players being put in the driver's seat of change, with the government in a supporting role. The article argues that this raises significant questions on the nature and role of construction of publics in network governance. 


\section{Introduction: Livestock Farming in the Netherlands under Challenge}

Dutch livestock farming is a prime example of a sector facing complex challenges concerning its sustainability and social license to operate. Many actors, meetings and publications, often extensively referring to and building on each other, have stated and restated the need for reform, suggesting an emerging consensus - at least on this starting point-among a considerable number of key players. Sicco Mansholt, a former Minister of Agriculture who is widely seen as one of the architects of modern agriculture in the Netherlands, spoke in 1995 of intensive livestock farming as 'a system of organized irresponsibility' (Aarts et al. 2010, p. 2). In 2001, a prominent advisory committee (the Wijffels Committee) concluded that the dominant pathways of development in livestock farming in the Netherlands had gone beyond what was acceptable and permissible in the eyes of society in a number of areas, including animal welfare, public health and the environment. The committee concluded that there was no future for employing strategies rooted in cost efficiency and price competition for Dutch livestock farming, because such strategies were out of line with societal demands. The committee also stressed the necessity of far-reaching reform in livestock farming to achieve sustainability and a future-proof license to produce (Denkgroep Wijffels 2001). In 2003, the Minister of Agriculture, Cees Veerman, concluded that 'we import feed, export pigs and keep the garbage here. The system is deadlocked' (Aarts et al. 2010, p. 2). In response to these concerns, new visions and plans for the future were mapped. The Ministry of Agriculture, Nature Management and Food Quality (2008) charted a 'future vision for livestock farming', addressing many of the challenges identified in the Wijffels Committee's report. In 2009, stakeholders from the sector, together with governmental and societal representatives, began a long-term collaboration through an 'Implementation Agenda [for] Sustainable Livestock Farming' (http://www.uitvoeringsagendaduurzameveehouderij.nl). However, the slowness of progress has been noted repeatedly by both stakeholders and observers. In response, in 2010, 
105 university professors decided to publish a 'Plea for Sustainable Livestock Farming: An End to Organized Irresponsibility'. The plea states the following:

Now, in 2010, we can establish that the Wijffels Committee's doom scenario has come true almost completely, and has also moved beyond that. We've been confronted with Q-fever, livestock-associated MRSA ${ }^{1}, \mathrm{ESBL}^{2}$ and the threat of an $\mathrm{H}^{5 N 1^{3}}$ pandemic, and the effects of intensive feed industry and livestock farming have become even clearer. In the years in which the Committee's proposed measures ought to have been executed, hardly anything has been done with the recommendations. Instead, livestock farming has become even more intensive, still at a large scale healthy animals are being culled, animal disease crises still form a large threat to public health and the living and slaughtering conditions of hundreds of millions of animals in our 'civilized' country are still disgraceful (Aarts et al. 2010, p. 5).

For many years, actors have called for structural improvements to the current conditions. As part of this process, building on the arguments and sense of urgency documented in previous years, the sector and other actors have initiated interactions and collaborations through network governance processes. As Maciel (2015) noted regarding animal welfare governance, responsibility in this context has increasingly been placed in private hands. This raises questions about the role of society in livestock farming governance, particularly as animal welfare and other issues surrounding livestock farming are frequently important public concerns. How do actors involved in livestock farming governance relate to society, how is society engaged in policy processes, and what are implications of this societal engagement for how problems and solutions are understood? Although questions of societal legitimacy have been prominent in the literature on livestock farming governance, societal engagement in governance processes has received little attention. 
To explore these questions, the present study examined a particularly pertinent case of livestock farming governance that took place subsequent to the discussions and developments charted above. The Dutch government organised a two-day meeting on the scale and future of livestock farming in the country, involving prominent leaders and key stakeholders from different domains. The meeting produced a report that different ministries and other actors subsequently considered, responded to and integrated into their visions and plans. This meeting was a good example of network governance in action. It brought together key private and public actors, many of whom had repeatedly interacted and collaborated in preceding years. The meeting was attended by representatives of organisations speaking for the sector (including farmers, the feed industry, and the meat and dairy industry), retail, finance, civil society (environmental and animal welfare organisations and a residents' group), local and provincial government organisations, and health, research and knowledge institutes. These attendees comprised approximately 40 people, who were often leaders in their (mostly nationally prominent) organisations. Representatives of the organising government organisation (a ministry) were present as observers. Participants generally shared a history of interaction, involvement with the issue, basic understandings of the issue, and a cordial form of relating with each other. They came together over the shared objective of contributing to the resolution of the unsustainability of the Dutch livestock farming sector. Although a prime objective of the dialogue was to chart the differences and agreements among the attending actors and to identify possibilities for action to be reported to the organising ministry, the facilitator sought to go beyond this and sought to take steps towards collaboration among the participants through the dialogue.

Many themes, challenges, ways forward and conditions were addressed during the meeting, including, for example, the need for integral approaches, the place of agriculture in the Dutch landscape, the need for shared ambition and the necessity of enforcing agreements across the sector. Society was both an important backdrop and a topic in its own right. During the 
meeting, participants consistently engaged with society as part of the problems and solutions, through the construction of publics. Publics are conceptualised here as mediated, fluid and unbounded groupings of people invoked by the meeting participants, based on (forged) connections between them, as categories of people whom the reforms would need to take into account. This article focuses on how the meeting participants constructed and engaged with two key publics: 'The citizen' and 'the consumer' were presented as central to the problem of achieving more sustainable forms of livestock farming. The meeting participants invoked and foregrounded 'the consumer' in their deliberations, thus marginalising citizens as a constructed public, as well as the civil society organisations present at the meeting. An issue of urgent public concern that drove the legitimation of the meeting was transformed into a question of consumer responsibility. Constructions of publics thus shaped the course and outcome of the deliberations. In this way, the network governance of livestock farming depoliticised an issue of concern to citizens while reinforcing and legitimising market solutions and taking market interests as the starting point, despite the fact that the highly politicised issues of sustainability and societal legitimacy were the very reason for the meeting being held. This article charts how this happened and makes a case for the wider relevance of the analysis.

\section{Theoretical Framework}

\section{Governance}

In the Netherlands, as in other European countries, livestock farming governance increasingly involves non-state actors. Producers, retailers, NGOs and government agencies collaborate to set standards and develop marketable concepts for more sustainable or animal welfarefriendly products (Bock and Buller 2013; Maciel and Bock 2013). This process is in line with Dutch government policy in past decades, which promotes market-centred solutions to 
societal challenges and needs, adjusting its role accordingly - an approach that is increasingly accompanied by debate and concern about the consequences for public goods (Stellinga 2012). Livestock farming is one area where this type of policy has been applied. Rather than acting as a regulator, the government has positioned itself as a supporter and facilitator, calling upon the sector to address issues of concern. In turn, within the livestock farming sector and among other stakeholders, there have been numerous initiatives to change practices in the sector through multi-stakeholder engagement. Many of these initiatives can be understood as instances of network governance, where interdependent but operationally autonomous actors from the public and/or private sectors interact through ongoing negotiation in a relatively institutionalised framework with regulative, normative, cognitive and imaginary elements. Network governance is seen as facilitating self-regulation in the shadow of hierarchy and contributing to the production of public purpose in the broad sense of public values, visions, plans, standards, regulations and concrete decisions (Sørensen and Torfing 2007 in Torfing and Sørensen 2014). Network governance has become a common feature in many societies. Scholarship and practice have broadly welcomed network governance for its supposed aim and ability to 'respond to complex, conflict-ridden and illdefined policy problems by facilitating negotiated collaboration among public and private stakeholders on the basis of interdependency' (Marcussen and Torfing 2007 in Torfing and Sørensen 2014, p. 334).

However, a key concern regarding network governance is democratic quality (Bogason and Musso 2006; Papadopoulos 2007). First, network governance structures and operations tend to be relatively invisible to society. Second, access to the networks is limited, as their composition is determined using criteria that prioritise expertise and power in the context of an issue over inclusiveness. Third, accountability towards society is generally weakly developed. Much of the discussion about these matters concerns the networks' structuration, management and operations. Democratic quality issues have also been noted for livestock 
farming governance, specifically. Examples include the power of retail over producers and the dominance of moderate viewpoints to the exclusion of more radical ones (Maciel 2015; Maciel and Bock 2013). However, to this point, in livestock farming governance and in other domains, there has been little attention given to another dimension of democratic quality: With their relatively thin institutionalisation and their talk-centred nature, networks can be expected to constitute problems, solutions and the democratic acceptability of these discursively while relating to the society in which they are embedded. This is particularly relevant for livestock farming and other agricultural policy areas because of the wide and deep societal concern and engagement with connected issues of environment, food and health.

\section{Publics}

The network governance literature has not engaged with the matter of relating discursively to publics, but some research has been conducted on the construction of publics in the context of policymaking and politics. In this existing work, publics are usually conceptualised as mediated, fluid and unbounded groupings of people that come together, or are brought together, through interaction over themes and issues, on the basis of some (forged) connection in terms of shared views, experiences or interests. Published work has focused on how publics are constituted through public communication and become public actors. Publics are constituted through multiple means, including, for example, discursive practices (e.g. claims of representation, discursive appeals) and forms of engagement or disengagement (e.g. opinion research, forms of participation), that advance certain understandings of publics (e.g. Braun and Schultz 2010; Mahony et al. 2010). Theorists conceptualise the formation of publics to take place in diverse senses. Publics are constituted through summoning-imagining, prefiguring and calling upon (Mahony and Clarke 2013), as well as through their convening - by their being addressed, their response and circulation of discourse (Warner 2002). Publics are 
also constituted by their assemblage, by calling together and building connections between individuals and interests using techniques such as persuasion, claims of representation, imagery and seduction (Goodie and Wickham 2002; Griffin 2010). In this way, publics are constructed as actors, and, depending partly on how their nature and role as publics are brought into being, they may play certain roles in political action, including mobilisation, contestation and negotiation. The construction of publics, then, is seen as part of a complex interplay between actors in a context (Newman and Clarke 2009). The existing literature has focused on publics as constituted through practices that, while ambiguous and fluid, create and shape publics into some form of actor in public life (e.g. engaging with an issue, speaking out or performing or negotiating roles).

Literature is limited on the democratic quality of the construction of and engagement with publics in present-day politics. One line of research addresses the processes reshaping the nature and role of publics (Clarke 2011; Marquand 2004) and publicness in neoliberal politics. Two key examples of this research, both focused on the United Kingdom, concern the recasting of the public domain and the publics within it (Newman and Clarke 2009) and the foregrounding of the 'consumer' in conceptions of citizenship under New Labour (Clarke 2011). This work shows how practices of relating to publics are important activities that shape the publics' political identities, roles, actions and voice. Arguably, this importance stretches far beyond the discursive practices in neoliberal politics on which existing work has focused. The rise of network governance, combined in many contexts with the retreat of institutional politics, raises important new issues regarding how, and with what consequences, publics are constructed. Prior research has identified some of these issues. Braun and Schultz (2010), discussing the ways organisers of participatory exercises construct publics, noted a certain tendency to construct publics in a way that allows for harmonious, supposedly win-win constellations that theoretically can benefit everyone, at the expense of more conflictual or antagonistic topics. Further, Griffin (2010) has shown how the construction of publics in 
European Union fisheries governance raises important questions about the criteria for inclusion, as well as the democratic consequences of the forms of representation, inclusion and exclusion of publics.

However, to this point, there has been little analysis of the construction of publics woven into processes of deliberation in governance. Understanding the role of publics in contexts of network governance is important. Networks' democratic quality not only depends on how they relate to the society in terms of visibility, access and accountability. They can also be expected to construct their relations with society and legitimacy through the deliberation itself - in how society itself is conceived. In this article, I show how the analysis of this deliberation reveals the nature and importance of a form of constructing publics that has not been identified or problematised in previous work: the invoking of publics as a key element in deliberation in the context of governance. To introduce, validate or invalidate courses of action, certain publics and their positions are suggested and inserted into arguments on the nature of problems, as well as solutions and their feasibility. These constructions largely emerge from the sector itself, as the key players in the network meeting, and marginalise the oppositional positions that lie at the very basis of the 'urgency' of the meeting - the citizens' voices asking for change. This is where we move now.

\section{The citizen-consumer paradox}

Although a fundamental starting point for the meeting on the future of Dutch livestock farming was the loss of societal legitimacy for the sector, the main public constructed and engaged with in this meeting was a consumer public whose behaviour needed to change to overcome a citizen-consumer paradox - a notion that as citizens, people may hold certain standards, while as consumers, they disregard the same standards and act against them. This paradox, also called the 'citizen-consumer gap' (Vermeir and Verbeke 2006), has been identified and 
explored in other research on livestock farming and meat production, as well as food consumption more broadly (Aerts 2013; De Bakker and Dagevos 2012; Gómez-Benito and Lozano 2014). This research has focused on consumer understandings, attitudes and behaviours, also exploring how these areas can be approached so that public goods such as the sustainability of food production or animal welfare can be advanced based on a proper interpretation. This past work, in part, has built upon and developed the citizen-consumer paradox or gap (Vermeir and Verbeke 2006). Other research has problematised the focus on individual and intended behaviours in this research line. Thorslund and Lassen (2016), for example, showed the need to understand values as having different relevance in different contexts - an understanding that leads to the insight that, to promote certain consumer behaviours, it can be useful to appeal to what is value-making in the specific context of everyday shopping and eating (e.g. by presenting animal welfare as a cue for eating quality) (2016, p. 18) rather than presenting information, for instance. Other research (Aerts 2013) has challenged the usefulness of the citizen-consumer paradox/gap concept by pointing to the promise of progress towards production that is more animal welfare-friendly or more sustainable through negotiated shifts in product availability (e.g. to non-battery eggs), which circumvent the citizen-consumer paradox instead of addressing it. Some literature fruitfully deconstructs the citizen-consumer paradox, analysing the many ways in which politics and consumption are intertwined in many ways, institutional and informal: development and introduction of animal welfare and environmental labels; the advancement of political consumption in the form of boycotts and buycotts; development of voluntary simplicity, slow food and other lifestyle movements. All these are evidence that the distinction between consumption and politics, and thus also the paradox, can be seen as an artifice (see e.g. Johnston 2008; Haenfler et al. 2012; Parker et al. 2017).

The same literature, however, while helpfully moving away from the idea of the consumer as a calculating, rational actor, and showing how the market is a political place, centres on market- 
or consumer-led solutions for issues that pertain to public concerns that could well be addressed through more conventional democratic politics, possibly leading to public policy. In the present case, such a path could have been considered as an option. However, this was effectively moved away from, employing a consumer-citizen paradox in its most basic form, denying not only the complexity of relations between the two notions, but, moreover, the role of democratic politics and public policy as such.

Participants in the meeting on livestock farming in the Netherlands conceived of a paradox in straightforward terms, as consumer conduct being inconsistent with citizens' demands, although both were implicitly understood as different sides of the same public. This citizenconsumer paradox/gap formed the foundation for the arguments meeting participants developed for market-centred interventions as solutions to sustainability problems - getting consumption to satisfy citizen demands, in effect emptying out citizenship as an independent category of significance to the dialogue. At the same time, conceptualisations of relations of the livestock farming sector with publics became complicated over the course of the meeting, resonating with some recent complexifying academic research (e.g. Aerts 2013; Parker et al. 2017).

\section{Depoliticisation}

Invoking publics in this way was fundamental to the development and legitimation of a perspective that privileges problem analyses and solutions protecting the interests of the powerful actors who were present. The meeting shifted what the participants themselves understood as a heavily politicised legitimacy crisis for the sector away from the public sphere and towards mutual producer-consumer relations (cf. Clarke 2011). This, as I will show, undermines the democratic quality of such a deliberation to address the societal challenge at hand, and it also raises issues with regard to effectiveness. This is not to suggest that the 
construction of publics in itself created a new situation; it was rather that the construction of publics expressed power relations in terms of decision making around livestock governance and implicitly and unreflexively established the terms for the identification of viable solutions. We can see the dialogue thereby as depoliticising the problem. Depoliticisation is here to be understood, following Flinders and Buller (2006: 55), as a process of altering arenas where decisions are made, in this case theoretically insulating decision making from political pressures.

\section{Methods}

I took part in the meeting as an observer. It took place over two days and resulted in $\mathbf{1 7 . 5}$ hours of deliberation, which was recorded and transcribed. The transcript was analysed through discourse analysis, studying language in use. The construction of publics through discourse is understood here as a communicative achievement attained through the utterances of the participants, the back and forth between them, and their combined contributions (Wetherell et al. 2001). Through these, certain meanings were presented, reinforced and foregrounded, or marginalised over the course of the deliberation. The discourse analysis entailed asking a set of specific questions of the material: What publics are being constructed, and by whom? How are publics characterised? How do specific publics figure in arguments about problems, their causes and their solutions? Participants' statements were inductively and iteratively coded and then further analysed to identify the patterns that emerged in how publics were invoked and used in the deliberation. Which constructions are more or less prominent? How do constructions of publics contribute to the construction of problems, causes and preferred solutions? In other words, how does the construction of publics contribute to the consideration of policy on the problem at hand? 
This analytical approach should not be taken to imply that meanings were formed entirely in the moment of speaking. The meeting was a single instance in the course of many interactions over several years on the issue of livestock farming in the Netherlands. Many participants were exposed to, or participated in, parts of these broader interactions in a national political context where market-centred solutions had been advanced for years. It can be assumed that the participants drew on already existing and shared understandings and ways of speaking about publics. Nevertheless, through the meeting, such understandings and ways of speaking were shared and disseminated in a new context, and meanings were reinforced and put to new use.

To protect the identity of the meeting participants, all utterances were anonymised in this article, and I have chosen not to disclose the exact details of the meeting, which was one of several bringing together stakeholders in livestock farming in the Netherlands over the past few years.

\section{The Case}

At the beginning of the meeting, the facilitator charted its starting points and objectives. Based on previous interactions, he stated that it was clear already that those present acknowledged the problems and the urgency of developing and enacting solutions. 'You all say "things must change", he said, 'so together we can say we are going to look for the best solution'. Although the prime objectives of the meeting were to chart differences and agreements among the actors and to identify possibilities for action, the facilitator sought to go beyond this:

What do we need for those agreements-not just the intention, but to really make that shift happen? What would be necessary for that, what could we do about that and who should play what role in that? 
The facilitator approached the event as a dialogue, in the sense that it was intended to identify and integrate different perspectives, knowledges and interests while exploring innovative solutions. He also approached the event as a moment for identifying options for setting in motion a process of change involving the actors present as key players who, together, would play a leading role in making that change happen. Thus, although the meeting was officially a consultative one meant to lead to a report for a government organisation, it was also designed to be a cooperative meeting, in the sense that the facilitator aimed for collaboration among the participants.

During the meeting, it became increasingly clear that the participants shared a number of starting points when it came to problem assessment. The participants commonly stressed the urgent need for more sustainable livestock farming and for regaining their social license to operate. In past years, scale enlargement had become a problem in terms of social acceptance and landscape, participants agreed, and future enlargement would only make this worse. Issues related to the environment and animal welfare also needed to be addressed. Public health risks associated with fine dust and animal disease were important concerns acknowledged by the participants, although these risks and what scale enlargement could mean for them was partly uncertain. The social position of farmers in their localities was a concern as well, especially for pig farmers. Along with all of these issues and the need to address them came the concern for a viable business model for farmers, who were faced with combining producing for markets with meeting societal demands. Particularly important here was the widely lamented experience that societal demands mean little in the marketplace. Consumers mostly put price considerations ahead of sustainability considerations, making it impossible for farmers to make the demanded changes. Presently, there is no mechanism to pay for sustainable production. Much of the meeting explored identifying and assessing options. 


\section{Results}

Citizens figured as an important construct in the meeting. First, the participants broadly acknowledged that society questions the sector's license to operate and that this can be expected to continue and potentially to increase greatly. As a representative of a dairy farmers' organisation put it, 'Of course we are here today primarily because a certain sector is not accepted by society'. A representative of an environmental organisation also noted that 'the primary interest is that trust in this society's own livestock farming sector is rebuilt'. It was mostly, but not exclusively, representatives of civil society organisations who discussed or spoke for citizens and articulated claims about what citizens think and expect from the sector. Participants often made claims about the urgency of the problem of societal acceptance and trust in general terms, describing a challenge to their social license to operate, the evidently high salience of the issue of livestock farming and the low societal acceptance of the sector. However, these challenges often manifest through mobilisation around specific issues. Connected with these issues, the meeting participants said that citizens show their dissatisfaction through resistance and the voicing of demands concerning a range of issues, including animal welfare, public health, livestock numbers, the size and appearance of stables and the need to protect landscapes and the environment.

The meeting participants did not always agree with citizens' priorities. However, consistently, when they brought up citizens' demands, it was to imply that the sector had to change. A representative of an association of residents protesting the scale expansion of livestock farming in their area made the following claim:

Behind those citizen initiatives [citizens' groups protesting the expansion of farms] is a very large group. Very many groups of civic resistance, very many citizens often living 
in the direct vicinity of mega-stables who are confronted with these on a daily basis [and] who remain unheard to this day.

The meeting participants identified citizens' priorities, thereby also constructing a public of citizens as sharing a view and having a voice that must be heard and attended to by those present. For example, a representative of a farmers' organisation stated that it was important for the sector to perform above the minimum legal requirements when it comes to sustainability standards:

There is a priceless added value in that. To show the citizens in this country: Look, we take the concerns in society seriously. This cannot be expressed financially, because if we don't do this it will probably be finished soon; the farmers will get the axe.

Referring to a public opinion survey carried out as part of the ministry's exploration of views on livestock farming in Dutch society, a representative of a dairy farmers' organisation made the following argument:

I think it is good that the citizen simply says, 'I don't want to be at risk with my health and I want animal welfare to be strengthened'. Those were the main points of the citizen in this country. The environment is important of course but less tangible. When it comes to prioritisation, the survey is much more important than whatever we here have to say.

Some participants constructing the public of citizens also claimed that this public can be expected to become a true danger to the sector if demands are not addressed. Along these lines, a representative of an environmental organisation, discussing developments in the North Brabant province, where scale expansion of an already large sector has led to protest, made the following claim: 
What I am extremely worried about-around mega-stables in Brabant, there was much resentment against building still more stables, still more animals, and that has culminated around the $Q$ fever crisis. ${ }^{4}$ There it became immediately manifest to such a degree that people say, 'Now that's the limit'. So, that means that the acceptance of this sector and a manifestation of the sector in Brabant is slowly eroding.

For the same participant, the constructed public of angry citizens provides arguments for redesigning the sector:

This public health matter has only been that final trigger. You have to see how it could get so far with the system that we are where we are right now. I think we would be wise to draw that lesson and redesign a sector that doesn't have the design faults that it now so evidently has.

Constructions of a citizen public that no longer accepts the operations of the livestock farming sector tended to come mostly from civil society organisations, which employed such constructions in appeals to the sector to redesign itself. Participants from other stakeholder groups who presented views on this appeared more equivocal on the views of the public, challenging the unequivocality of citizen demands as well as the salience of these demands.. For example, as one participant claimed: 'Consumers-for one, animal welfare is important, for another, it's the environment, and for another still, it's health or the landscape'. Another participant claimed none of that matters all that much:

Consumer behaviour is driven by price, health, convenience, then nothing for a long time and then something with animal and welfare, and then nothing for a long time and then sustainability comes in somewhat. It doesn't drive consumer behaviour much.

The facilitator commented that 'it's not entirely clear how citizens experience livestock farming. What we know is insufficiently firm'. Moreover, civil society's pleas for the redesign of 
the livestock farming sector elicited little response from the other participants. Such claims and associated demands for action were thereby marginalised in the exploration of the problem and potential solutions undertaken during the course of the meeting.

This does not mean that the participants, beyond the civil society organisations and some scientists, do not acknowledge that there is a problem that deserves to be addressed. Participants commonly stated their acceptance that the demands of 'the citizen' need to be addressed, and some general statements were made on the need for dialogue with citizens. However, such statements remained removed from the discussion of possible solutions and issues to resolve. Once solutions were on the table, the type of publics brought in were adjusted to the type of solution. In the tabling of solutions that found some acceptability across a wide range of participants, the interests of the sector were a starting point. Solutions must be financed. Participants, most prominently those associated with the sector (like farmer organisations, meat industry) consistently stressed that a viable business model is a precondition for innovation. The fundamental problem here, such participants stated, is that, while 'the citizen' makes demands, 'the consumer' tends not to be ready to pay. A representative of the meat industry summarised this as follows:

If you ask citizens what they expect from livestock farming or from meat, they make extraordinarily impressive statements about people's behaviour. But in the wallet, when they go shopping, something very different happens. That is a tremendous dilemma in the shift towards sustainability, and its speed. Part of that will lead to higher costs, and these must be paid somewhere.

This argument expresses the existence of a citizen-consumer paradox: Citizens make claims to institutions (including private actors) to advance their conception of the good, while consumers make choices prioritising low cost. The paradox was restated in multiple instances and forms: 'There is a societal pressure towards adding value in the sector, but at the same 
time a struggle with the fact that in the market it isn't possible'. 'Dutch citizens are fed up with intensive livestock farming. Dutch consumers can't be bothered. We have to resolve this conflict of interests'. This paradox is at the basis of how the meeting evolved. Discussion centred on how to overcome the citizen-consumer paradox.

The meeting participants developed arguments on possible interventions towards sustainability based on the assumed reality and relevance of the citizen-consumer paradox and the clear-cut separation of the two notions. As for engagement with citizens and their demands, the meeting focused on devising solutions for the impasse posed by the paradox. The solutions emerging from the meeting have important consequences for how 'the citizen' gets to be engaged with addressing livestock farming as an issue of public concern. 'The citizen' was not approached as a public to be addressed, deliberated or negotiated with. Rather, the consumer-citizen construct imagines the citizen-consumer as a single body of a people with two faces, contradictory in nature and necessary to make coherent, thereby resolving the paradox. The consumer public, then, also does not come in as having an interest or view that needs to be included. The way to achieve coherence between 'citizen' and 'consumer' is the transformation of consumer behaviour.

Participants associated with the sector stressed that the market has a defining role in the future of livestock farming. Sustainability was thus described as a shared consumer responsibility, with producer actions to be 'made possible' by the consumer. 'Higher demands must be paid for by higher results in the market', a representative of the meat industry argued. A representative of a pig farmers' organisation made the following claim:

If we leave this room tonight and we say, 'we're going to be tough and set the bar high', we sign the death warrant of our farmers. 
Participants making such statements took a viable business model for the sector as a starting point for the addressing of the legitimacy crisis, taking the meeting of sector needs as a precondition. The key question was consistently about how to make consumers pay more. An agricultural researcher made the following argument:

We haven't made the consumer an accomplice. We remain focused on the citizen. But we need to involve the consumer, who is to be made co-responsible for the images for which he wants to pay or not.

With the repeating of such statements by participants from diverse stakeholder groups over the course of the meeting, the exploration of solutions engaging with citizens' concerns was narrowed to the exploration of options for shifting to more sustainable production through higher market prices. This involved market concepts, the restriction of consumer choice, and reconnecting farmers and consumers. Although non-sector participants contributed to the deliberations throughout the meeting, the conceived solution of overcoming the citizenconsumer paradox narrowed the discussion to such an extent that other participants did not engage with interventions alluding to 'redesign' from starting points other than overcoming the paradox through the transformation of consumer behaviour.

\section{Market Concepts}

Participants often mentioned the retail sector as a crucial player in the shift towards sustainable meat production. The argument is that the practice of continuing to offer cheap meat to survive in the market keeps the production and sale of unsustainable meat going, and something has to happen to take that pressure away. One option that was considered is the development of market concepts around sustainability and quality that differentiate the meat market, adding value to what are now mostly commodities with little distinction between them beyond price. The participants proposed that product differentiation through market 
concepts addressing different citizen concerns could link consumption and citizenship by shifting consumer behaviour to meet citizen demands. Such market concepts concerned certification systems raising the bar for producers in terms of the sustainability of production. However, this is not a clear-cut path to take. Sustainability is not easily integrated into a market concept for meat. A representative of a retail branch organisation explained this as follows:

\footnotetext{
Sustainability is not always easily communicated to the consumer. Animal welfare, that works. But when it comes to manure standards or biodiversity, things like that, it's limited if not impossible.
}

To the extent that promise was seen in market concepts, it was mostly in the option of participation across the sector in the Beter Leven (Better Life) certification system, or something comparable, still to be developed. The Better Life label, presently used by a range of meat producers and retail organisations in the Netherlands, is a certification programme for meat products adhering to animal welfare standards. This programme, which assigns one to three stars to meat products, is run by the Dierenbescherming, a prominent Dutch animal protection organisation. A representative of a farmers' organisation made the following comment:

You might have to consider making the Better Life label into a collective agreement. There are several pluses. The extra costs will be complied with by all. Retail will have to buy it and pass on the costs to the customer. Customers can't escape. You cover the societal acceptance, because you show the people, as a sector, we all are now at a higher standard and we have higher animal welfare. It was justified that you were angry, turned your backs to us, and lost confidence in us, because indeed it had gone wrong. But we have drawn our conclusions and together we have established this standard, so really everybody follows this line. 
Other 'pluses' mentioned by participants contributed to the positive reception of this option. One starting point here to make this a viable option was the idea that consumers would 'not care' about price once the cheaper choice is simply no longer available. Another starting point was the high legitimacy of the star system and the Dierenbescherming, whose endorsement would lend legitimacy to the sector. However, the meeting did not address what exactly would have to be certified with such a label, beyond animal welfare, or how that would meet societal concerns.

\section{Addressing Market Failure: Restriction of Consumer Choice}

Market concepts thus came to be discussed partly as ways to offer to consumers a constricted set of choices. Consumers not buying sustainable products is a case of market failure and demands intervention. Beyond market concepts, discussions of the possibility of collective agreements and regulation come in here, creating a level playing field for the sector, which was seen as a condition for the success of such an intervention, and the basis of the business model. Participants broadly accepted that price is a fundamental issue that would have to be addressed to deal with the race to the bottom induced by market discipline. A representative of an environmental organisation described this as follows:

The distinction between consumers and citizens-that is a really crucial one and that's why the market isn't working well, while at the same time there is social support for animal friendly meat and dairy. Individually, the consumer isn't capable, because, when you are in the supermarket and you see cheap meat, you think, I'm not going to be a fool. Everyone else is buying the cheap meat. Or you're really seduced well by the price.

'The consumer' needs to be 'protected' against inclinations to choose the cheapest products, this participant went on to argue. One key way to change consumer behaviour is to decide 
collectively to define and impose standards for meat products to be sold in Dutch supermarkets. This would require agreements across production chains, from farmer to retail, to produce and sell only more sustainable products. Constricted choices would also be easily accepted by consumers, some participants argued. One participant brought up the historic case of supermarkets successfully banning battery eggs in 1986; consumers accepted this change easily. A representative of a dairy farmers' organisation made the following claim:

If a product is not cheaper on the shelf, in principle, the consumer doesn't care. That citizen doesn't notice if it is five or ten cents more expensive. Only if the cheaper product is on the shelf. If not, it becomes a normal value.

However, some participants viewed collective agreements as legally impossible. A retail representative stated that anti-trust legislation would immediately block efforts to make agreements for standards above the legal minimum, including making a certification programme such as by Better Life collectively binding. For a few participants, this was itself a problem that needs to be addressed-if regulations block commonly desired change, the rules need to change. This issue was not taken up further, but the need for government intervention was broadly acknowledged in the sense that apparently, the problems cannot be resolved by the market alone. A representative of an environmental organisation asked, 'Can the consumer, as a citizen, obtain support from the government in the form of regulation?' This then became a question for the meeting. The government was seen as withdrawing and certainly not eager to regulate the sector. Participants tended to take as a starting point that the sector would be lead the shift towards more sustainability. However, the government was expected to play a crucial role in realising the 'level playing field' that participants saw as a 'precondition for shifting towards sustainable production. A representative of a farmers' organisation made the following argument: 
Surveillance of surveillance-the sector can do a lot by itself, but the government will needs to surveil the surveillance in order to guarantee that minimum requirements are met. But, through our thorough discussions, we have also established that the chain functions best when there is a minimum standard somewhere, or a sword of Damocles - that somebody organises something to fall back on when it comes to dealing with the unwilling, so to say.

In response to this possibility, some participants brought in the fact that the market for meat is a European one, with Dutch farmers facing competition with lower prices offered by foreign competitors. How could they collectively raise the prices of Dutch meat when the foreign competition's prices will remain lower? The possibility of the government enforcing sustainable production does not do away with this market reality, participants argued. A retail representative put this as follows:

Prices come about internationally. We've talked about this a lot, but with no results.

Price is decided by supply and demand in the European market. I'm terribly sorry.

Here, the restriction of choice, as a market-centred solution lauded during the meeting for its ability to marry sustainability and sector needs, was confronted with fundamental challenges in the form of the market and the rules that protect it.

Reconnecting Farmers and Consumers

A less prominent theme in the meeting addressing citizen concerns sought different forms of communication that could help to achieve societal acceptance of the sector. Some participants considered the potential of 'rebuilding' relations between farmers and consumers, addressing the divide between them in an anonymous marketplace resulting from current forms of production and sales. Promoting direct interaction between farmers and consumers could 
inform the latter about how famers 'actually' operate and enhance empathic understanding of farmers. Again, consumption is being considered as a pathway to sustainability. A representative of an environmental organisation put this as follows:

I'm looking for the creation of connections between producer and consumer.

Organizing that at the lowers possible scale, making consumer and producer mutually recognizable.

This interaction involves the human beings behind the products and means of production as well as the shifts these people are in the process of undertaking. A representative of a bank highly involved with the sector made the following argument:

A cattle farmer must enter into dialogue with society to clarify what needs to be considered-the role of the cattle farmer as a person and how he adopts responsibility and communicates are very important in the whole process. More than what production standards are applied, exactly.

Such a relation would contribute to societal acceptance and therefore a license to operate, participants argued. That the anonymity of the marketplace is not easily overcome was also addressed. The scale enlargement taking place, leading to ever larger farms, might render interaction with consumers an increasingly unlikely option to educate and convince citizens of the legitimacy of the livestock farming sector.

A related possibility to address citizens' concerns was that of educating and persuading citizens on the legitimacy of meat production. Communication about the sector's efforts to become more sustainable, the dilemmas involved, the complexity of innovation, and information on ongoing innovation processes and achievements would contribute to a better image of the sector, decreasing citizens' apprehensions about the sector-apprehensions that, in the eyes of the participants, are also due to the invisibility of the changes that have been achieved. 
Participants asserted that many people think 'nothing has changed', and they need to be made aware of the improvements that have taken place and of the efforts underway. A representative of a pig farmers' organisation argued as follows:

Together, you have to show society what issues you are struggling with and what that demands of you. And that you're working on things. That it can't be done in a day, but you demonstrate that you are taking responsibility. The image in society is, 'nothing is going on', but a lot has been done. This means you haven't communicated it or shown it.

Additionally, some participants argued that education on the implications of different consumer choices and the promotion of more sustainable choices could expand the market for this meat. Surely, consumers choose, but they can be helped with proper campaigning to make conscious choices 'for health or this or that', as one participant said.

In short, awareness raising and the enhancement of knowledge through informative and persuasive communications could contribute to both sector legitimacy and sustainability. However, in a number of instances during the meeting, other participants stressed that the market for sustainable meat is a niche market and will remain just that, again downplaying the possibilities the market offers for overcoming the challenges at hand.

\section{Market Solutions for a Political Problem}

Market concepts, the restriction of consumer choice, and reconnecting farmers and consumers were proposed solutions systematically centring on financing more sustainable forms of production through strategies that change consumer behaviour. The shift to more sustainable production was consistently constructed as a responsibility shared between consumers and producers, with participants suggesting that producers are more in line with citizen demands than is publicly apparent. Consumers' unwillingness to pay more keeps producers in line with 
the market principle of price competition but out of line with citizens. Consumers choose poorly because of the market forcing the sector to engage in a race to the bottom. Companies within the sector, including farmers, the meat industry and retail, cannot afford to produce and market only more sustainable forms of meat if other companies do not follow the same policy. The solution to this problem is to keep the market in check by softening its control over the sector, intervening in the market to reshape consumer behaviour, supposedly salvaging sustainability as well as the sector and its license to operate in the eyes of citizens. In this way, the concept of the sovereign consumer, central to marketisation and neoliberalism, is undermined. The free market is manipulated to shift consumer choices, in order to serve citizen views while protecting producer interests and following the idea of sustainable farming that farmers also accept. The interests of citizens and producers are thus constructed as similar, united against those of the consumer who is guided by low prices alone. This tension is neutralised by arguing that, in the end, low prices are 'not really' something consumers care about, once the cheap choices are taken out of view.

This paper started out from the idea that the discursive construction of publics matters to the way the meeting unfolded, suggesting that it is reasonable to ascribe power to discourse. One may question to what extent we can ascribe power to discourse here, in and of its own; one may argue that what we see here is power to govern in the hands of the sector (cf. Maciel 2015), as the sector that is granted a leading role. However, discourse, implicitly, unreflexively, and hidden from public view and scrutiny, defines and delimits the imaginable forms of interaction with society and the nature of solutions here. First, the solutions that are imagined as 'viable' are those that meet that criterion of looking through the prism of producerconsumer relations with the goal of a viable business model as a precondition. Second, the resolution of problems is to happen through private, everyday consumption decisions, rather than public, political processes. The meeting shifted what the participants themselves 
understand as a heavily politicised legitimacy crisis for the sector towards a realm of mutual producer-consumer relations and away from the public sphere. Similar to Clarke's (2011) description of the United Kingdom's Labour government's way of constructing the citizenconsumer in the context of public services, citizens' concerns were accepted into the meeting only through the figure of the consumer. Relations between the livestock farming sector and the citizens who challenge the sector's license to operate are imagined as individualised (contained in the consumptive actions of individuals and their individual interactions with sector actors) and particularised (contained in these consumptive actions and interactions rather than being allowed to involve other actions or forms of influence over the sector). Third, the views of 'the citizen', while fundamental to the whole matter, were not engaged directly. Although a number of oppositional voices from civil society seeking to represent citizen publics were present, their voices were marginalised when they raised appeals to redesign the sector. Further, these oppositional voices were generally marginal in the deliberation as the voice of society, as compared with the influence of the construct of an (actually absent) consumer public. In addition, several civil society organisations actively contributed to the construction of consumer publics and the need to overcome the citizenconsumer paradox. In this way, the citizen's voice was constricted in terms of acknowledgment and engagement. Although some citizen views were seen as present, legitimate and urgent in terms of the claims made, it is the consumer who must change to bring about the changes 'the citizen' wants. Following Clarke (2011), then, the analysed meeting depoliticised livestock farming. It disconnected relationships between the public and livestock farming that included political dimensions. 'The citizen' was the 'problem' behind the sector's deteriorated social license to operate, but the space for solutions was systematically delimited. Contestation was displaced, as direct engagement with citizens and their concerns was avoided. The apparent pattern of seeking win-win solutions acceptable to the sector first and foremost, made logical through taking the citizen-consumer paradox as a premise and prioritising consumers within a 
market logic, minimised contestation, despite the fact that several oppositional voices were in fact present. How consumer behaviour would address the breadth of citizen concerns was not discussed. Ideas of how the proposed market solutions would address, for example, concerns about farm scales, public health issues or societal demands constricting the sector as such were not taken up. Engagement with citizens as citizens was only brought in through a few general and disembodied statements on the need to 'enter into dialogue with citizens'. There was no deliberation on the proposed dialogue involving, for instance, the concretisation of who, what or why, because no such process was envisaged. The main possibility for discussion doing more justice to citizens' perspectives and the politics of the matter-representative democracy-has been side-lined by a government that puts its faith in 'the market' to take the lead in handling the problem of agricultural sustainability. At the meeting, the alignment between the government and the sector regarding this was evident and reinforced. With the government seen mainly in the role of a potential supporter of sector-led initiatives towards repairing a 'market failure' and civil society organisations seen only in the role of potential endorsers of such initiatives, the restricted breadth of conceivable understandings of problems, solutions and strategies in this instance of 'network governance' is notable. This was the case although participants in the same meeting pointed at significant barriers to the proposed solutions that were put in place by the market: international competition, anti-trust legislation, difficulties with 'marketing sustainability' and expectations of consumption of more sustainable meat likely remaining a niche market.

Participants spoke of the challenges to market solutions as given and in line with the market focus of this supposedly inclusive deliberation. There was no call for broader societal or political engagement on the matter, nor were there attempts towards engagement with citizen publics to address their stance and role in the supposed crisis. On its side, the national government, considering initiatives like this one and their outcomes, has consistently asserted its starting point that the market is in the lead; the government has generally described its 
own role in terms of facilitation and support (see e.g. Ministry of Economic Affairs 2013, 2016; Ministry of Economic Affairs, Agriculture and Innovation 2011).

In the end, while ostensibly giving prime importance to citizens and their concerns, the instance of network governance analysed in this article reinforces the market as the site where collective futures are charted, disregarding the tensions faced in terms of the democratic quality of the policy process and the resolution of the problems of sustainability and sector legitimacy. Implicitly, participants also seem to accept and reinforce the market as a political arena; in particular by exploring options for market interventions to redirect consumer choices. In this sense, the dialogue partly overcomes the overly simplistic distinction between consumption and politics that it advances. The results of this analysis suggest the wider significance of the construction of publics in the governance of issues such as livestock farming, where public concerns and market interests intertwine and clash in complex ways, and where governance involves a significant yet implicit form of rethinking of relations between market and politics. This is particularly the case when network governance is widely conceived as potentially able to address complex and 'wicked' problems and advance public goods. This is not to suggest the network governance of livestock farming is necessarily less effective than state-led policymaking. Indeed, in line with the understandings and ambitions charted in this particular meeting, multi-stakeholder initiatives led by sector actors rooted in collectively defined and endorsed higher production standards (e.g. 'the Chicken of Tomorrow' [Kip van Morgen] and 'the Pig of Tomorrow' [Varken van morgen]) have come about in the past few years. These initiatives (accompanied by anti-trust challenges, as pointed to in the meeting) are intended to work towards higher sustainability and animal welfare standards across the meat market in the Netherlands. Such initiatives can contribute to creating the level playing field needed to face the consumer as constructed in the meeting. 


\section{Further research}

Moving beyond this case study: considering the widespread of stakeholder dialogue, the results point to the importance of addressing certain questions regarding the construction of publics in network governance more broadly. The implicit sidelining of citizen voices observed, limited exploration of other and possibly more structural solutions as well as the democratic quality of the dialogue. This suggests the need to learn much more about the nature and role of public-invoking in network governance in other contexts and around other issues. In particular: How does the foregrounding of publics figure in the discursive inclusion or exclusion of viewpoints and interests in society, as well as in conceptualisations of problems and solutions? What does this tell us about how power is executed in networks that include citizen groupings, as in the case examined here? What does this tell us about network governance's capacity to address and include oppositional voices that are often at the basis of the 'wicked problems' the networks are called upon to engage with and resolve - in particular addressing the role of market actors as key participants in network governance? How could engagement with publics in network governance be enhanced to advance democratic quality and legitimacy?

\section{References}

Aarts, N., R. Aerts, F. Ankersmit, A. Arntz, C. Baalen et al. (2010) Pleidooi voor een duurzame veehouderij. http://www.wanttoknow.nl/wpcontent/uploads/pleidooi voor een duurzame veehouderij.pdf (Accessed August 11 2016) Aerts, S. (2013) The consumer does not exist: overcoming the citizen/consumer paradox by shifting focus. Pp. 172-176 in H. Röcklingsberg and P. Sanding eds., The ethics of consumption: the citizen, the market and the law (Wageningen: Wageningen Academic Publishers) 
Bock, B. and H. Buller (2013) Healthy, happy and humane: evidence in farm animal welfare policy. Sociologia ruralis 53 (3) pp. 390-411

Bogason, P., \& Musso, J. A. (2006). The democratic prospects of network governance. The American review of public administration 36 (1) pp. 3-18

Braun, K. and S. Schultz (2010) '...A certain amount of engineering involved': constructing the public in participatory governance arrangements. Public understanding of science 19 (4) pp. $403-419$

Clarke, J. (2011) Citizen-consumers: hyphenation, identification, de-politicization? Pp. 225-242 in K. Brückweth ed., The voice of the citizen consumer: a history of market research, consumer movements, and the political public sphere (Oxford: Oxford University Press)

De Bakker, E. and H. Dagevos (2012) Reducing meat consumption in today's consumer society: questioning the citizen-consumer gap. Journal of agricultural and environmental ethics 25 (6) pp. $877-894$

Denkgroep Wijffels (2001) Toekomst voor de veehouderij: agenda voor een herontwerp van de sector. http://www.novatv.nl/data/media/db_download/132_13a808.pdf (Accessed July 10 2016)

Flinders, M., \& Buller, J. (2006). Depoliticization, democracy and arena shifting. Pp 53-81.in T. Christensen, and P. Lægreid, eds., Autonomy and regulation. Coping with agencies in the modern state (Cheltenham: Edward Elgar Publishing)

Goodie, J., and G. Wickham (2002) Calculating 'public interest': common law and the legal governance of the environment. Social \& Legal Studies 11 (1) pp. 37-60

Gómez-Benito, C. and C. Lozano (2014) Constructing food citizenship: theoretical premises and social practices. Italian sociological review 4 (2) pp. 135-156 
Griffin, L. (2010) Fishing for the public interest: making and representing publics in North Sea fisheries governance reforms. Pp. 107-126 in N. Mahoney, J. Newman and C. Barnett, eds., Rethinking the public: innovations in research, theory and politics (Bristol: The Policy Press) http://www.uitvoeringsagendaduurzameveehouderij.nl (Accessed June 15 2016) Haenfler, R., Johnson, B., \& Jones, E. (2012) Lifestyle movements: Exploring the intersection of lifestyle and social movements. Social Movement Studies 11(1) pp. 1-20.

Johnston, J. (2008) The citizen-consumer hybrid: ideological tensions and the case of Whole Foods Market. Theory and Society 37(3) pp. 229-270.

Maciel, C.T. (2015) Public morals in private hands? A study into the evolving path of farm animal welfare governance ( $\mathrm{PhD}$ thesis, Wageningen University)

Maciel, C.T. and B.B. Bock (2013) Modern politics in animal welfare: the changing character of governance of animal welfare and the role of private standards. International journal of sociology of agriculture and food 20 (2) pp. 219-235

Mahony, N. and J. Clarke (2013) Public crises, public futures. Cultural studies 27 (6) pp. 933-954 Mahony, N., J. Newman and C. Barnett (2010) Introduction: rethinking the public. Pp. 1-14 in N. Mahoney, J. Newman and C. Barnett, eds., Rethinking the public: innovations in research, theory and politics (Bristol: The Policy Press)

Marquand, D. (2004) Decline of the public: the hollowing out of citizenship (Malden: Polity Press)

Ministry of Agriculture, Nature Management and Food Quality (2008) Toekomstvisie op de veehouderij (The Hague: Ministry of Agriculture, Nature Management and Food Quality) 
Ministry of Economic Affairs [Ministerie van Economische Zaken] (2013) Kabinetsstandpunt inzake omvang intensieve veehouderij en schaalgrootte (The Hague: Ministry of Economic Affairs)

Ministry of Economic Affairs (2016) Kamerbrief Commissie Duurzame Veehouderij (The Hague: Ministry of Economic Affairs)

Ministry of Economic Affairs, Agriculture and Innovation [Ministerie van Economische Zaken, Landbouw en Innovatie] (2011) Visie veehouderij (The Hague: Ministry of Economic Affairs, Agriculture and Innovation)

Newman, J. and J. Clarke (2009) Publics, politics and power: remaking the public in public services (London: Sage)

Papadopoulos, Y. (2007) Problems of democratic accountability in network and multilevel governance. European law journal 13 (4) pp. 469-486

Parker, C., Carey, R., De Costa, J., \& Scrinis, G. (2017) Can the hidden hand of the market be an effective and legitimate regulator? The case of animal welfare under a labeling for consumer choice policy approach. Regulation \& Governance advance access.

Stellinga, B. (2012) Dertig jaar privatisering, verzelfstandiging en marktwerking (Amsterdam: Amsterdam University Press)

Torfing, J., \& Sørensen, E. (2014). The European debate on governance networks: Towards a new and viable paradigm? Policy and Society, 33(4) pp. 329-344. 
Vermeir, I. and W. Verbeke (2006) Sustainable food consumption: exploring the consumer 'attitude-behavioral intention' gap. Journal of agricultural and environmental ethics 19 (2) pp. 169-194

Thorslund, C.A. and J. Lassen (2016) Context, orders of worth, and the justification of meat consumption practices. Sociologia ruralis. Online first. doi: 10.1111/soru.12143

Warner, M. (2002). Publics and counterpublics. Public culture 14(1) pp. 49-90.

Wetherell, M., S. Taylor and S.J. Yates, eds. (2001) Discourse as data: a guide for analysis (London: Sage)

Zamwel, E., O. Sasson-Levy, and G. Ben-Porat (2014) Voluntary simplifiers as political consumers: Individuals practicing politics through reduced consumption. Journal of Consumer Culture 14 (2) pp. 199-217

\footnotetext{
${ }^{1}$ Meticilline-Resistant Staphylococcus Aureus

2 Extended Spectrum Beta-Lactamase

${ }^{3}$ Hemagglutinin Type 5 and Neuraminidase Type 1 (Avian Influenza A).

${ }^{4}$ The speaker refers to the outbreak of $Q$ fever in the area around 2009, leading to the infection and death of a number of people.
} 